\title{
Does Wealth Influence Women's Labor Participation Decision?: Evidence from Egypt ${ }^{1}$
}

\author{
Fatma El-Hamidi \\ Graduate School of Public and International Affairs \\ University of Pittsburgh, PA
}

Tel: (412) 372-0895

Fax: (412) 372-5324

E-mail: fatma@pitt.edu

August, 2004

The author is grateful to Ragui Assaad and Deborah Levison for invaluable guidance.

${ }^{1}$ A preliminary version of this paper was presented at the $11^{\text {th }}$ annual ERF conference in Marrakesh, Dec. 2003. The author is grateful to comments made by Heba El-Laithy, Lynn Squire, and Insan Tunali. 


\begin{abstract}
$\underline{\text { Abstract }}$
This study examines the behavior of labor supply of women at different levels of household wealth status. It is widely demonstrated in the literature that variables such as age and level of education, as well as the demographic, social, and financial characteristics of the household influence deciding to join the labor market. However, this study argues that these determinants work differently according to the level or the well-being of the household, adding another to the literature on women's labor supply in MENA.

There have been few studies on women's labor supply in the MENA region. Some have focused on labor supply and its elasticities in Egypt and Turkey [El-Hamidi (2003), and Tunali and Baslevent (2000)]. Others have focused on the fertility and timing of marriage in Morocco [Assaad and Zouari (2003)]. Household wealth is yet to be considered in the labor supply analysis.

Only recently a couple of studies have handled the role of poverty in labor supply. Eberharter (2001) shows a difference between the gender role in the labor market between those above and below the poverty line in Germany. Dessing (2002) points to different labor supply elasticities for different wage rates in the Philippines.

I start with the assumption that social and traditional gender roles, as well as economic factors, govern women's participation decision in the labor market. This assumption is sustained only when household income/ wealth is above a specific threshold. When household income falls below some threshold, only economic factors matter in the decision to join the labor market. Ultimately, economic hardships are likely to press women to work more hours. In this paper, there is evidence that responsiveness of hours of work, resulting from a change in wages, vary according to wealth level of the household. Several policy implications emerge from negative labor elasticity: the need to impose a minimum wage to avoid repeated cycles of poverty, as well as providing specialized training and education programs.
\end{abstract}




\section{Introduction}

Women labor has become an important factor in household income, thus improving the living conditions of double earnings families, and providing a barrier against economic instability and high levels of men's unemployment. Besides, as women become more economically independent and contribute more to family subsistence, power within the household tend to be more liberated, further improving the social status of women [Babb (1990)].

The focus on women's supply in Egypt is motivated by two simple facts: first, while women represent at least half the population in Egypt, they account for $27 \%$ of total workforce ${ }^{2}$ compared with $73 \%$ of their men's counterparts ${ }^{3}$ in 1998 . Second, is the liberalization of the economy, and implementation of stabilization and privatization policies required by the IMF. The Egyptian practice of public sector employment guarantee continued for decades and offered the highest rewards of education and experience in the labor market. Until the mid 1980s, and despite partial liberalization in the mid 1970s, known as the "open door policy", the public and government sectors dominated the labor market by absorbing greater numbers of educated and experienced workers. The decade between 1988 and 1998 witnessed a rise in the pace of liberalization towards a market-led economy. Public sector employment guarantee came nearly to an end by early 1990s, and employment in the public and government sectors started to decline. The burden of these restructuring policies is heavily borne by women, either directly or indirectly. If Egypt is to make effective use of its wealth of population, these shares have to change, which cannot be achieved unless women engage in the labor force in greater numbers. By understanding women's participation behavior, policy makers will be in a position to assess the likelihood of satisfying this adjustment, forming effective policy prescriptions, and drafting proposals to invoke work incentives.

The analysis in this paper focuses on urban women, ages between 15 to 64 . The choice of this subsample leads to rather reliable results, urban women are most likely to be engaged in government and public sector jobs that are heavily affected by the privatization policies.

The objective of this paper is to test the assumption the canonical model of labor supply does not work at low levels of wages (or income). The second objective is to test if factors that determine labor supply decisions differ according to the economic well-being of the household where the worker lives. In this study, I argue that labor supply elasticities differ according to the level of wealth of the household where the worker lives.

The rest of the paper is organized as follows: Section 2 is a theoretical background on the labor supply model and the new research on the link between poverty level and the decision making process. Section 3 presents a review of the literature. Section 4 lays out the econometric model. Section 5 covers the data and variables handling. Section 6

\footnotetext{
${ }^{2} 15$ years or older

${ }^{3}$ Source: ILO Bureau of Statistics, for 1998.
} 
discusses empirical findings. Finally, Section 7 provides closing remarks and recommendations.

\section{Theoretical Background:}

The traditional, or canonical, labor supply model views a family as a single decision making unit, and any factor affecting the husband's role in the labor market, provokes a response in the woman's labor participation decision. In other words, women assume a secondary role with regard to the labor supply of the family.

Some empirical studies have shown that at low levels of income the substitution effect dominates, resulting in a positive elasticity of labor supply (raising wages raises hours of work). At high wage levels, the income effect dominates resulting in a negative elasticity (raising wages reduces hours of work). As a result, the labor supply schedule takes the C shape (backward bending) [Robins (1930)].

The drawback of this model is that it does not offer a clarification on whether, and to what extent, these effects differ at different levels of wages or income . Dessing (2002) shows how this traditional labor supply model fails to capture the behavior of poor workers. In practice, especially in the developing world, as wages fall, workers work longer hours to maintain a living wage, representing negative labor supply elasticity.

During the 1960's, there was evidence of negative labor supply (long hours of work at low wage levels). This development resulted in a backward bending labor supply schedule occur at low levels of income [Berg (1961)]. Most of the research done during that period focused on farmers and peasants which were presumed to have different needs and desires, therefore different preferences for work and leisure time. According to Berg (1961), Myrdal (1971), and Lipton (1983), those workers preferred leisure over work once they reached the minimum level of subsistence income, after which they reduce their work hours. Others such as Schultz (1964), Miracle and Fetter (1970), Gollas (1972) and Miracle (1976) offered a different interpretation. They argued that poor living conditions at those times and high rates of mortalities were enough incentives for workers to go back home once they satisfied their minimum needs. Others went a different route. Hanoch (1965), Barzel and McDonald (1973), and Sharif (1991), among others, used the Cobb-Douglas utility function to explain the negative elasticity of supply at low wages.

\section{The Reversed S-Shaped Labor Supply Model:}

Dessing (2002) provides a different interpretation of negative labor supply elasticity. One of the basic assumptions of the canonical model, is the reservation wage is a primary factor in determining whether to participate in the labor market or not. The reversed $\mathrm{S}$ shaped model, however, assumes at very low levels of income, the family must devote all capable members to engage in work to cover their basic needs. This is what Dessing referred to as "forced employment". At income below the subsistence level, only the income effect dominates, and leisure is considered a luxury good, producing a labor supply that is negatively sloped. When basic needs are met, the labor supply shrinks (backward bending portion) that is when workers decide to free some of their market work time for leisure or homework. 
The canonical model emerges when family income exceeds subsistence level. The labor supply schedule slopes upward suggesting a positive substitution effect, then slopes backward because of a negative income effect. At extremely low levels of income, the family cannot cover expenses necessary to engage in the labor market (transportation, clothes, ...), and in exceptional cases, some family members may not be able to maintain the physical effort needed to complete the job and they are trapped into "forced unemployment".

Employment in urban Egypt is dominated by government and public sectors as the primary employer, where working hours in these institutions are fixed in general (Assaad, 2002). Therefore, full-time, primary wage earners in urban families seldom change their work hours with changes in wages. Secondary workers on the other hand, which includes married women and older children, also called "supplementary" or "added" workers, work at low levels of wages to meet basic needs. The traditional role of women in Egypt is mainly to produce for the family: caring for other family members, and ultimately responsibility for the survival of the family. That is why near the subsistence level, families increasingly depend on the added income of the secondary workers. Domestic work remains the responsibility of the woman even after joining the labor market and working long hours. That puts an added burden on women. That load converts to an incentive to lessen the long working hours when basic needs are met, to further improve the welfare of the family by taking care of the domestic activities. At intermediate levels, they withdraw from the labor market and substitute work with leisure. The substitution effect dominates, and they experience a positive elasticity of labor supply. At higher levels of income, several domestic tasks are transferred to the market, which concurrently free some hours for women to spend in the labor market. Besides, people engage in new consumption patterns and social status calls for joining the labor market.

\section{3- Review of the Literature:}

Women labor supply studies on the US and other advanced countries are many compared with those of developing countries. These studies have produced a wide-range of conflicting estimates of labor supply elasticities on wages and income. In their comprehensive survey of that literature, Killingsworth and Heckman (1986) conclude estimates of women labor supply elasticities in these contexts are large, both in absolute terms and relative to men's elasticities. The wage elasticity estimates vary widely from 0.85 to over 14 , depending on the data source, the sub-populations studied (which vary by age group, marital status, and race) and the statistical methodology used. Killingsworth and Heckman (1986) list a wide range of positive estimates of wage elasticities. Nakamura, Nakamura, and Cullen (1979) obtained a negative uncompensated wage elasticity. Killingsworth (1983) attributes this result mainly to excluding the schooling variable from the hours equation. Another possible source of this result is the lack of a work experience variable in the wage equation, and/or the selection terms.

Most studies of women's labor supply in the developing world focus on the labor force participation decision rather than the hours-of-work decision, therefore elasticity. 
Sahn and Alderman (1988) estimate a labor supply function for Sri Lankan men and women using 1980-1981 data. They found the elasticity of labor supply for wages is positive and lower in urban than rural areas $(0.14$ for rural men, 0.07 for urban men, 0.15 for rural women, and 0.03 for urban women).

Connelly, DeGraff and Levison (1997) compared the determinants of participation in employment with the determinants of hours worked for urban Brazilian women using 1985 household survey data. Because there are large proportions of households headed by unmarried women in Brazil, the authors divided their sample into women whose husband was present and single women heads of households. They found the unobservable factors that increase the likelihood of employment of single women heads caused their hours of work to decrease, once employed. For women with spouses, unobservable factors worked in the same direction for both participation and hours worked.

Dessing (2002) analyzed 99 low income rural households between 1975 and 1976 in the Philippines. He reported negative elasticities of -0.39 to -0.46 for secondary workers in the household. Assaad and El-Hamidi (2001) produced elasticity estimates for Egyptian women using 1988 data. They found a $10 \%$ increase in wages results in a $3.4 \%$ increase in hours of work. In summary, the existing research points to low elasticities of women's labor supply for wages in developing countries.

Alas, these studies did not consider testing for labor supply elasticities at wealth rates or income levels. Few studies reported differences in labor supply elasticity by wage level. Sharif (1991) studies wage and self-employed labor supply elasticities of landless and near landless farmers in India using 1970 and 1971 data. His data showed a forward falling labor supply schedule at low wage levels and an upward sloping schedule at higher wage rates. But he does not show if this falling forward occurs below subsistence level. Dessing (2002) found a negative elasticity for women at low wage rate (-.39). Eberharter (2001) also found differences in participation practices between women below and above the poverty line in Germany.

\section{The Econometric Model}

The impact of labor market conditions on the labor supply decision is typically captured by the wage rate that depends on the individual's education and labor market experience [Killingsworth and Heckman (1986), Sahn and Alderman (1988), and Schultz (1995)]. According to of labor supply theory, the participation decision is based on a comparison of the market wage a woman earns and her reservation wage, the wage below which no labor is supplied [Killingsworth (1983), and Killingsworth and Heckman (1986)]. The reservation wage is related to the opportunity cost of a woman's time at home (or in unpaid work), her unearned income, as well as other factors that may affect her preference for paid work, relative to other time uses. Thus, the labor supply function may be written as a function of the wage rate, other earnings and preferences.

While an increase in the wage rate clearly increases the likelihood of labor force participation, the effect on the number of hours supplied is not as obvious, since both 
income and substitution effects come into play. The final decision depends on the marginal utility of consuming market goods and services purchased with wage income, relative to that gained from added "leisure" time. This puzzling connection between labor force participation, the wage rate, and hours of work creates the need to know how hours respond to wages, if at all.

One of the problems typically discussed in labor supply models is selectivity bias. Selectivity bias in wage and labor supply models was first discussed by Gronau (1974), Lewis (1974), and Heckman (1974). They argued that employed workers are those who are offered higher "market" wages than their "reservation" wages. As a result, the subsample used for determining of wages and hours of work represents a non-random sample of the population. As Vella (1998) explains: selectivity bias is a result of the unobservable characteristics that is correlated in both wages and hours equations.

Heckman (1980) suggested a solution [Heckit], which is used here. By identifying two equations: the selection (participation) equation, which models the probability of engaging in paid work for all the observations in the sample using standard probit/ ML technique to single out the employed from the non-participants. To correct for sample selection, parameter estimates from participation equations are used to estimate a variable $\lambda$ (called the selection term), is then included in the outcome equation, which applies only to those who are observed in paid work. In this analysis, the observed outcomes for those who engage in paid work are either hours or wage. Although the Heckman selection model is written for hours of work $H$, the same equations apply well to the wage $W$. This procedure presents the advantage that it solves simultaneously the two problems that appear when estimating a simultaneous equation model, sample selection (selectivity) bias and endogeniety.

Finally, and once selectivity-corrected reduced form wage and hours equations are obtained, structural versions of the labor supply equations can be estimated by introducing the predicted wage as a regressor in the hours equation. This is referred to as estimation procedure (VII) by Killingsworth and Heckman.

Because of the joint determination of wages and hours of work equations, there are two issues to be considered. First, if wages and hours of work are simultaneously determined, it is inappropriate to use actual wages in the hours equation. Second, the wage equation has to include variables excluded from the hours equation so the predicted wage will not be perfectly collinear with the hours equation regressors. To account for the parabolic relation between age and the life- cycle of labor supply decisions, the age-squared is used as an independent variable. Fuchs (1989), and other empirical studies show that women experience a shorter and more interrupted spells of labor market attachment, than men. Therefore, the influence of squared age on women's labor supply is expected to be weak (and probably negative). Regional differences in labor opportunities are captured by regional dummies. Where Greater Cairo is the reference, Alexandria and Suez Canal Cities, Urban Upper Egypt and Urban Lower Egypt are three other dummies.

The estimated hours and wage equations may be expressed as: 


$$
\begin{aligned}
& \ln (w)=\delta_{x w}{ }^{\prime} x_{w}+\delta_{w}{ }^{\prime} \hat{\lambda}+\xi_{w}, \\
& \ln h=\delta_{x h}{ }^{\prime} x_{h}+\delta_{V} V+\delta_{w} \ln (\hat{w})+\delta_{h}{ }^{\prime} \hat{\lambda}+\xi_{h} .
\end{aligned}
$$

Here, $x_{w}$ stands for the vector of regressors in the wage equation (age, age-squared, experience, experience-squared, education dummies, region dummies, and the estimated $\lambda$ to correct for selectivity); and $x_{h}$ denotes the vector of regressors in the hours equation other than the wage (age, age-squared, education dummies, and other factors that influence hours of work, but not the wage rate, such as: the number of children, other men's earnings $V$ - a proxy for non-labor-, and the estimated $\lambda$.). The hats (“^”) indicate the estimated versions of the $\lambda$ 's are being used and $\xi$ is a zero-mean, heteroskedastic disturbance term, which is uncorrelated with the right hand side variables. The wage equation includes dummy variables that distinguish between different regions of residence. Since there is no theoretical reason justifying including of region dummies, they are excluded from the hours equation. Linear regression of (1), (2), and the generated regressors $\hat{\lambda}$ would yield consistent estimates of the regression parameters. The structural version of the hours equation allows to estimate wage elasticity. This linear specification of the hours equation is the most often used form in the literature. It is hypothesized to see different patterns of participation to vary according to the level of wealth/ income.

Based on the previous discussion, the elasticity of labor supply with respect to own wage $w_{i}$, usually called the gross or uncompensated wage elasticity, is assumed to be negative for workers at the lower end of the wealth continuum. According to the standard neoclassical labor supply model, the elasticity of labor supply $h_{i}$ with respect to other men's earnings $V$, and the number of children, should be negative if leisure is a normal good.

\section{Data and Variables}

The empirical analysis is based on a 1998 nationally representative ${ }^{4}$ household survey, Egyptian Labor Market Survey (ELMS). The survey includes extensive data on basic demographics, employment, unemployment, occupational history, migration, education, earnings, and parental background. The ELMS 1998 was conducted on a sample of 5,000 households.

The survey collected data on hours and earnings. For regular workers (defined as continuously employed workers), annual hours of work were estimated by multiplying the average number of hours per day and the average number of days per week by the number of weeks worked per year. Wages for these workers were then estimated by dividing annual earnings by this estimate of annual hours. For irregular workers with more periodic employment, the reference year was divided into four quarters and the workers were asked about the number of months worked per quarter, the average number of days worked per month, the average number of hours worked per day, and the average wage per day each quarter. An estimate of the number of hours worked per year was

\footnotetext{
${ }^{4}$ In all but the five remote border governorates.
} 
then obtained by adding the estimated quarterly hours. The hourly wage was obtained by dividing the average daily wage over the four quarters by the average length of the working day across the four quarters ${ }^{5}$.

In contrast to the number of days worked per month, neither of these two variables varies much across quarters resulting in reliable estimates of hourly wage for irregular workers. There is, however, a significant room for measurement error in estimating work hours for irregular workers using this method because of recall problems and possibly some desire by such workers to under-report the number of hours they supply. However, the low proportion of irregular workers among women wage workers (2\%) makes such measurement problems trivial.

As widely agreed upon, the more educated women, the more likely to be employed. To account for the strong correlation between human capital and labor supply, dummies for the highest level of education reached are included. They are: illiterate (the reference category), able to read and write, primary education, preparatory education, secondary education, university education, and post graduate education. Experience (calculated as the number of years since entering the labor market for the first time), and experience squared/100 are two independent variables in the wage equation. As widely known, experience is considered one of the factors in wage determination.

Studies of women in developing countries confirm that it is a common practice in the literature on the economics of women's labor supply to account for individual and household characteristics that limit an individual's labor supply, such as the number of children, and wealth, or unearned income. Such information on household composition has been known to capture constraints and/or preferences regarding participation. The argument is that children affect one's current taste for working by raising the value of home time, but not one's value to an employer. I follow the mainstream of the literature and include the number of children 0-2 and the number of children 3-6, in the analysis.

Because the survey does not provide a measure of unearned income, another instrument is used: the sum of total earnings of other adult men family members in the same household, on the assumption that, in Egypt, men employment decisions are exogenous to those of their women's. A significant and negative coefficient on other men earnings underlines the complementary role of leisure and income, if leisure is a normal good. Zabel (1993) for example, obtained a negative relationship between individual's annual working hours and the household's income situation.

The variable used to measure the wealth of the household where the worker lives is proxied by a wealth score that is constructed using principle component analysis "Factor analysis" $"$. The wealth variable is a combination of three types of indicators: durable goods, housing assets, and financial assets. Durables include measure such as: fridge, freezer, TV, etc. Housing assets include: flooring types, number of rooms, access to

\footnotetext{
${ }^{5}$ The survey did not provide wage data for the self employed. To get around this problem, wages for self employed were predicted after running Heckman selection equation, and then plugged into the wage variable.

${ }^{6}$ This method is adapted from Assaad and Levison (2003), and Filmer and Pritchett (2001).
} 
electricity, etc. The financial assets contain: dividends on assets or interest on bank accounts. ${ }^{7}$

The main use of principal component analysis is to reduce the size of a data set while retaining as much information as is possible. It calculates a compact and optimal description of the data set. The first principal component is the linear index of all the variables that captures the largest amount of information that is common to all the variables and explains the greatest amount of variation.

Table A-1 in the appendix lists scoring coefficients for the wealth factor using maximumlikelihood estimation technique, without rotation, and keeping one factor. This factor captures the most common information between variables. This index has a mean of zero and standard deviation of $0.943^{8}$. A change from zero to one increases the asset score by (scoring coefficient / S.D.) of the variable. For example, a household that owns a fridge has an asset index that is 0.35 higher than a household that does not. Owning a car raises a household asset index by 0.18 units and so on. A new variable is then created containing the percentiles of the factor score- that is the wealth index. I set up cutoff values for the wealth index and sort individuals accordingly. The cut off values are set arbitrarily at lowest $20^{\text {th }}$ percentile, $20^{\text {th }}-40^{\text {th }}$ percentile, $40^{\text {th }}-60^{\text {th }}$ percentile, $60^{\text {th }}-80^{\text {th }}$ percentile, and highest $20^{\text {th }}$ percentile $\left(80^{\text {th }}-100^{\text {th }}\right)$.

Table A-2 in the appendix displays the means of the assets included in first principal component for private wage workers and self employed, for each cut off category. Some large differences appear to the average ownership of these assets. For example, owning a kerosene stove is $84 \%$ for the lowest $20^{\text {th }}$ percentile, and it is almost non existing at the highest $20^{\text {th }}$ percentile $(1 \%)$. Having water heater on the other hand is almost universal for the highest $20^{\text {th }}$ percentile $(96 \%)$, and it makes up $0 \%$ for the lowest $20^{\text {th }}$ percentile. Some assets have minor differences between all five groups such as: having access to piped water.

The difference in the average index between $20^{\text {th }}-40^{\text {th }}$ percentile category and lowest $20^{\text {th }}$ percentile category is 1.07 . An example of a combination of assets that would produce this difference is owning an electric fan (0.449), owning a fridge (0.304), and the availability of waste collection (0.203). The average asset index is 0.563 units higher for those in the $40^{\text {th }}-60^{\text {th }}$ percentile than those in the $20^{\text {th }}-40^{\text {th }}$ percentile. This difference is equal to having a sewing machine (0.183) and access to waste collection (0.383).

\footnotetext{
${ }^{7}$ A complete list of wealth measure in Table ( A-1)

${ }^{8}$ Theoretically, this index is a standardized variable with mean of zero and standard deviation of 1 .
} 
Using the asset ownership as a proxy for wealth (or income level) is a robust one. It accounts for the status of the household during a long period of time. As previously mentioned, I use different cut off points for the wealth indicator to compare the elasticity at different levels: lowest $20^{\text {th }}$, at $20^{\text {th }}-40^{\text {th }}$, at $40^{\text {th }}-60^{\text {th }}$, at $60^{\text {th }}-80^{\text {th }}$ and at highest $20^{\text {th }}$ percentiles of wealth distribution.

\section{Underlying Assumptions}

There are some key assumptions in this framework:

\# Once the participation decision has been reached, there are no restrictions on the hours supplied.

* The labor supply decisions of the husband is exogenous.

* Earnings reported by other men members in the same household are considered assets to the woman worker, and affects her labor supply decision.

* For this study, I assume those who fall below the $20^{\mathrm{th}}$ percentile of the wealth index are the poorest in the sample, followed by $20^{\text {th }}-40^{\text {th }}$ category and so on. Therefore, the higher the worker on the wealth index, the better-off she is in satisfying their basic needs.

The analysis is restricted to urban ${ }^{9}$, non-agriculture ${ }^{10}$ women, between the ages of 15 and 64 , and not currently enrolled in school, working in either public or private sectors or self employed, comprising $7 \%$ of all urban women in 1998, and about one third of the working sample. Wage workers working in the government sector were dropped from the working sample since their working hours are not tied to their fixed wage rate ${ }^{11}$. The sample on which the analysis is based on consists of 4843 urban women in 1998.

The analysis is also run for two combinations of the sample: one for self-employed and private wage workers, and another for self-employed and public and private wage workers, to see the effects with and without public sector employment. One reason is that in Egypt, the public sector is neither government nor private sector but has some characteristics of both sectors. Another reason is the low number of workers in that sector. Results of the later sample are reported in the appendix.

\section{Empirical Findings:}

\section{1- Preliminaries}

Table (1) below (and figure A-2 in the appendix) show types of employment distributed by cut off values of the wealth index. Private and public wage workers represented almost two thirds of total working sample - the majority working for the private sector, with a little over half the working sample (52\%), --while self-employed women

\footnotetext{
${ }^{9}$ Keeping with the literature, and to avoid the problems of labor market definition associated with subsistence agriculture in rural areas.

${ }^{10}$ High rates of seasonal employment within the agriculture sector are justification for excluding them from the analysis.

${ }^{11}$ In a previous version of this paper, the government workers were included in the analysis.
} 
accounted for $32 \%$. Table (2) below displays means and standard deviations of variables used in the analysis for private wage and self employed workers and by the five cut offs of the wealth index. Figure (1) also shows average yearly working hours by type of employment and wealth index cutoffs. In general, the mean age of the sample is 34 years. Almost half the sample (49\%) are highly educated, with university or post graduate degrees. Over half of the sample (57\%) resides in two metropolitan areas: Cairo, and Alexandria and Suez Canal. On average, $43 \%$ of the sample has infants, toddlers, and children ages between 0 and 6 years.

Table 1: Distribution of Urban Women By Type of Employment and Wealth Index Cut Offs

\begin{tabular}{|l|l|l|l|l|l|l|}
\hline Employment Status & $\begin{array}{l}\text { Below } \\
\mathbf{2 0}^{\text {th }} \\
\text { Percentile }\end{array}$ & $\begin{array}{l}\mathbf{2 0 - 4 0}^{\text {th }} \\
\text { Percentile }\end{array}$ & $\begin{array}{l}\mathbf{4 0 - 6 0}^{\text {th }} \\
\text { Percentile }^{\text {(60-80 }}\end{array}$ & $\begin{array}{l}\mathbf{8 0 - 1 0 0}^{\text {th }} \\
\text { Percentile }^{\text {Percentile }}\end{array}$ & Total \\
\hline Self Employed & 37 & 34 & 9 & 8 & 12 & 100 \\
Public Wage Workers & 3 & 3 & 4 & 18 & 23 & 51 \\
Private Wage Workers & 32 & 29 & 25 & 26 & 50 & 161 \\
Total & 72 & 65 & 38 & 52 & 85 & 312 \\
\hline
\end{tabular}

Table 2: Means and Standard Deviations of Variables Used in the Analysis, Private and Self Employed Workers, Urban Women, 15-64, Egypt 1998

\begin{tabular}{|c|c|c|c|c|c|c|c|c|c|c|c|c|}
\hline \multirow[b]{2}{*}{ Variables } & \multicolumn{2}{|c|}{$\begin{array}{l}\text { Total Sample } \\
\text { (Prv+S.emp) }\end{array}$} & \multirow{2}{*}{$\begin{array}{l}<20^{\text {th }} \\
\text { Mean }\end{array}$} & \multirow{2}{*}{$\begin{array}{l}\text { Percentile } \\
\text { Std Dev. }\end{array}$} & \multirow{2}{*}{$\begin{array}{l}20^{\text {th }}-40^{\text {th }} \\
\text { Mean }\end{array}$} & \multirow{2}{*}{$\begin{array}{l}\text { Percentile } \\
\text { Std Dev. }\end{array}$} & \multirow{2}{*}{$\begin{array}{l}\mathbf{4 0}^{\text {th }}- \\
\mathbf{6 0}^{\text {th }} \\
\text { Mean }\end{array}$} & \multirow{2}{*}{$\begin{array}{l}\text { Percentile } \\
\text { Std Dev. }\end{array}$} & \multirow{2}{*}{$\begin{array}{l}\mathbf{6 0}^{\text {th }}- \\
\text { 80 }^{\text {th }} \\
\text { Mean }\end{array}$} & \multirow{2}{*}{$\begin{array}{l}\text { Percentile } \\
\text { Std Dev. }\end{array}$} & \multirow{2}{*}{$\begin{array}{l}\mathbf{8 0}^{\text {th }}- \\
100^{\text {th }} \\
\text { Mean }\end{array}$} & \multirow{2}{*}{$\begin{array}{l}\text { Percentile } \\
\text { Std Dev. }\end{array}$} \\
\hline & Mean & Std Dev. & & & & & & & & & & \\
\hline Log Hourly Wage & 7.55 & 0.68 & 7.59 & 0.75 & 7.58 & 0.64 & 7.63 & 0.55 & 7.52 & 0.62 & 7.56 & 0.48 \\
\hline Log Yearly Hours & 0.05 & 0.82 & -0.27 & 0.44 & -0.10 & 0.42 & -0.01 & 0.86 & -0.02 & 0.68 & 0.39 & 0.69 \\
\hline Age & 33.51 & 12.28 & 33.41 & 13.30 & 35.50 & 13.00 & 29.97 & 10.85 & 30.97 & 9.25 & 33.17 & 12.23 \\
\hline Experience & 19.42 & 13.82 & 19.81 & 14.96 & 21.32 & 15.10 & 13.94 & 13.02 & 16.55 & 11.37 & 20.04 & 13.16 \\
\hline $\begin{array}{l}\text { Illiterate } \\
\text { (Reference) }\end{array}$ & 0.33 & 0.47 & 0.57 & 0.50 & 0.47 & 0.50 & 0.24 & 0.43 & 0.19 & 0.40 & 0.04 & 0.20 \\
\hline Read\&Write & 0.05 & 0.23 & 0.07 & 0.26 & 0.07 & 0.25 & 0.00 & 0.00 & 0.03 & 0.18 & 0.08 & 0.28 \\
\hline Primary & 0.09 & 0.28 & 0.10 & 0.30 & 0.15 & 0.36 & 0.06 & 0.24 & 0.03 & 0.18 & 0.17 & 0.38 \\
\hline Preparatory & 0.03 & 0.16 & 0.04 & 0.21 & 0.03 & 0.18 & 0.03 & 0.17 & 0.00 & 0.00 & 0.04 & 0.20 \\
\hline General Secondary & 0.02 & 0.12 & 0.00 & 0.00 & 0.00 & 0.00 & 0.06 & 0.24 & 0.06 & 0.25 & 0.00 & 0.00 \\
\hline University & 0.22 & 0.41 & 0.17 & 0.38 & 0.23 & 0.43 & 0.41 & 0.50 & 0.23 & 0.43 & 0.13 & 0.34 \\
\hline Post Graduate & 0.27 & 0.45 & 0.04 & 0.21 & 0.05 & 0.22 & 0.21 & 0.41 & 0.45 & 0.51 & 0.54 & 0.51 \\
\hline $\begin{array}{l}\text { Greater } \\
\text { Cairo(Referene) }\end{array}$ & 0.43 & 0.50 & 0.16 & 0.37 & 0.35 & 0.48 & 0.44 & 0.50 & 0.58 & 0.50 & 0.83 & 0.38 \\
\hline Alex.\&Sz Cnl. & 0.14 & 0.35 & 0.12 & 0.32 & 0.20 & 0.40 & 0.15 & 0.36 & 0.16 & 0.37 & 0.04 & 0.20 \\
\hline Lower Urban Egypt & 0.22 & 0.41 & 0.30 & 0.46 & 0.30 & 0.46 & 0.26 & 0.45 & 0.19 & 0.40 & 0.04 & 0.20 \\
\hline Upper Urban Egypt & 0.21 & 0.41 & 0.42 & 0.50 & 0.15 & 0.36 & 0.15 & 0.36 & 0.06 & 0.25 & 0.08 & 0.28 \\
\hline No. of Children $0-2$ & 0.17 & 0.38 & 0.14 & 0.35 & 0.17 & 0.38 & 0.24 & 0.43 & 0.10 & 0.30 & 0.04 & 0.20 \\
\hline No. of Children 3-6 & 0.26 & 0.44 & 0.30 & 0.46 & 0.15 & 0.36 & 0.29 & 0.46 & 0.35 & 0.49 & 0.13 & 0.34 \\
\hline $\begin{array}{l}\text { Log other Men's } \\
\text { Earnings }\end{array}$ & 3.27 & 2.85 & 3.01 & 2.65 & 3.07 & 2.74 & 3.70 & 2.82 & 3.86 & 2.94 & 4.04 & 2.99 \\
\hline No. of Observations & 261 & & 69 & & 63 & & 34 & & 34 & & 62 & \\
\hline
\end{tabular}

Source: Authour's calculations; ELMS

(1998) 
Figure 1: Average Yearly Working Hours By Wealth Index and Type of Employment, Urban Women, Egypt 1998

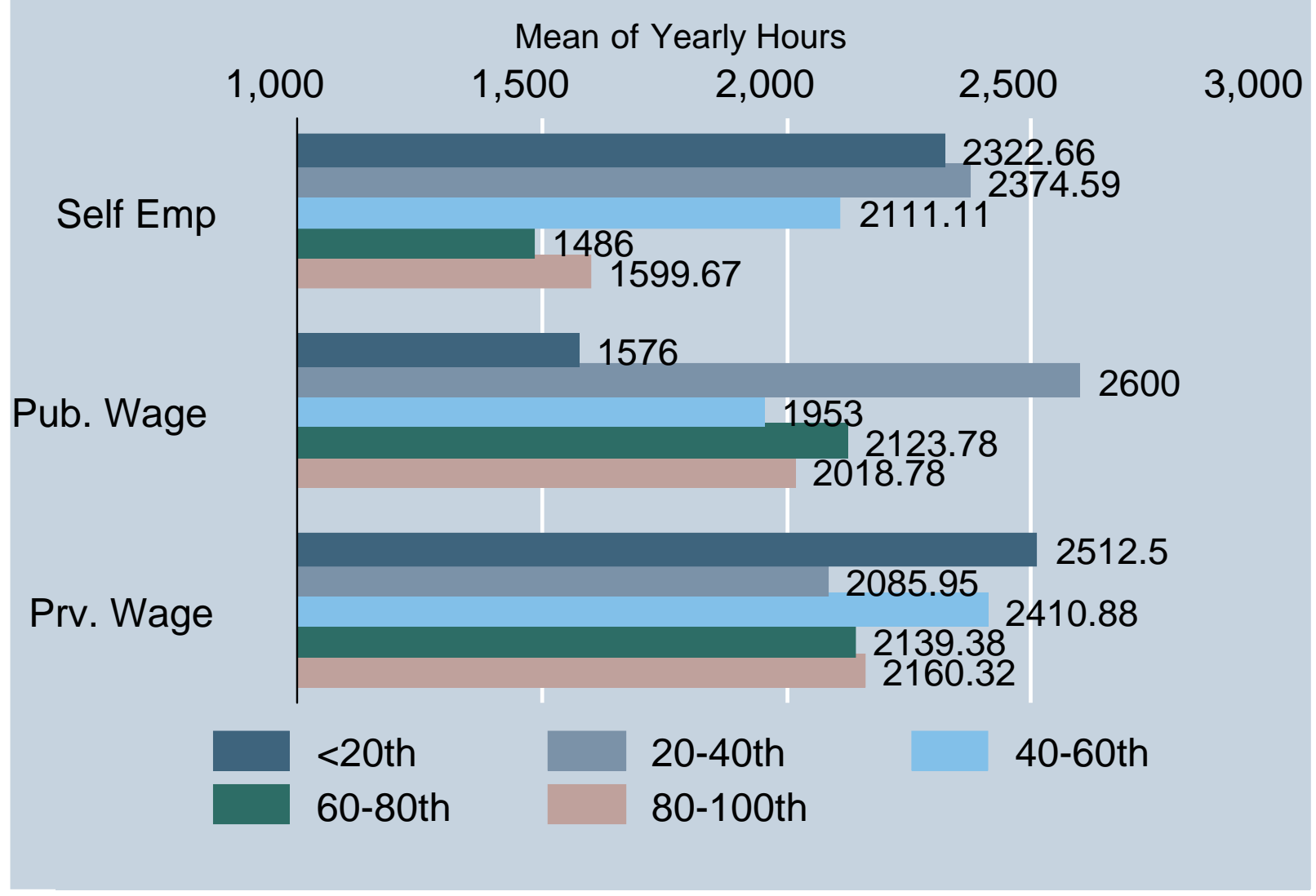

Figure (1) shows private wage workers to be the hard working group, and the lowest wage earners too (according to Figure A-1 in the appendix). Except for the second cut off $\left(20^{\text {th }}-40^{\text {th }}\right)$ they appear to be working more hours than the self employed or public sector workers. The figure also points to the fact that once self employed workers reach a higher level on the wealth index, they cut back their working hours, contrary to public and private workers. Public wage workers who fall in the second category $\left(20^{\text {th }}-40^{\text {th }}\right.$ percentile) seem to work the most of all workers in the sample. However, the small number of observations in this cell (3) makes it worthy of discounting. The reasoning applies to public workers falling in the lowest $20^{\text {th }}$ percentile of the wealth index.

Table (3) contains parameter estimates of the participation and wage equations (Heckman selection model). First, the insignificance of the selection term (inverse of mills ratio) is an indication that sample selection is not a problem. Tunali and Baslevent (2001) reached a similar conclusion. Negative age squared in the participation equation is an indication of shorter and interrupted spells of women's labor force participation.

The returns to experience in the wage equation show a concave experience-wage profile. 
Being able to read and write, at the primary or preparatory levels of education are significant determinants of participating in the labor force. Having a secondary or post graduate degree is significant determinant of wages rates. The existence of young children between 0 and 2 years does not have any effect on work decision, but children 3 to 6 years of age negatively influence that decision significantly. Contrary to classical theory assumption, other men's earnings in the household increase the likelihood of participation in the labor market, suggesting that leisure is not a normal good.

\section{Table (3): Participation and Wage Equations (Heckman Selection Model)}

\begin{tabular}{|c|c|c|}
\hline Variables & Participation Equation & Wage Equation \\
\hline Age & $\begin{array}{c}0.105 \\
(0.076)\end{array}$ & $\begin{array}{l}-0.033 \\
(0.037)\end{array}$ \\
\hline Age Squared & $\begin{array}{l}-0.093 \\
(0.110)\end{array}$ & $\begin{array}{l}0.053+ \\
(0.027)\end{array}$ \\
\hline Experience & & $\begin{array}{c}0.020 \\
(0.034)\end{array}$ \\
\hline Experience Squared & & $\begin{array}{l}-0.000+ \\
(0.000)\end{array}$ \\
\hline Ability To Read \&Write & $\begin{array}{l}0.322 * * \\
(0.000)\end{array}$ & $\begin{array}{c}0.036 \\
(0.074)\end{array}$ \\
\hline Primary & $\begin{array}{l}0.462^{* *} \\
(0.000)\end{array}$ & $\begin{array}{c}0.074 \\
(0.069)\end{array}$ \\
\hline Preparatory & $\begin{array}{l}0.552^{* *} \\
(0.000)\end{array}$ & $\begin{array}{c}0.167 \\
(0.125)\end{array}$ \\
\hline Secondary & $\begin{array}{c}0.365 \\
(0.300)\end{array}$ & $\begin{array}{l}0.224 * * \\
(0.021)\end{array}$ \\
\hline University & $\begin{array}{l}-0.409 \\
(0.345)\end{array}$ & $\begin{array}{c}0.259 \\
(0.310)\end{array}$ \\
\hline Post Graduate & $\begin{array}{l}-0.370 \\
(0.381)\end{array}$ & $\begin{array}{c}0.457 * * \\
(0.058)\end{array}$ \\
\hline Alexandria \& Suez Canal & $\begin{array}{c}0.372 \\
(0.333)\end{array}$ & $\begin{array}{l}-0.034 \\
(0.052)\end{array}$ \\
\hline Lower Urban Egypt & $\begin{array}{c}0.434 \\
(0.311)\end{array}$ & $\begin{array}{l}-0.041 \\
(0.050)\end{array}$ \\
\hline Upper Urban Egypt & $\begin{array}{c}0.464 \\
(0.307)\end{array}$ & $\begin{array}{l}-0.037 \\
(0.048)\end{array}$ \\
\hline No. of Children 0-2 & $\begin{array}{c}0.111 \\
(0.132)\end{array}$ & \\
\hline No. of Children 3-6 & $\begin{array}{l}-0.148^{*} \\
(0.089)\end{array}$ & \\
\hline Log HH Male Earnings & $\begin{array}{l}0.128^{* *} \\
(0.045)\end{array}$ & \\
\hline Constant & $\begin{array}{c}0.100 \\
(1.117)\end{array}$ & $\begin{array}{c}0.194 \\
(0.453)\end{array}$ \\
\hline Lambda & & $\begin{array}{l}-1.224 \\
(1.195)\end{array}$ \\
\hline No. of Observations & 4843 & 4843 \\
\hline
\end{tabular}

Source: Author's calculations; ELMS (1998)

Standard errors in parentheses

+ significant at 10\%; * significant at 5\%; ** significant at $1 \%$ 


\section{2- The Hours (Labor Supply) Equations:}

Table (4) presents results of hours equations for self employed and private wage workers at five different thresholds: below $20^{\text {th }}$ percentile, $20^{\text {th }}-40^{\text {th }}$ percentile, $40^{\text {th }}-60^{\text {th }}$ percentile, $60^{\text {th }}-80^{\text {th }}$ percentile, and $80^{\text {th }}-100^{\text {th }}$ percentile. The coefficients of predicted log wages are the elasticities for those falling within a threshold. Table (4) confirms the stated hypothesis. The uncompensated elasticity of hours supplied with respect to own wages is negative and significant at the 5\% level for the poorest group of workers. The same result applies to $20^{\text {th }}-40^{\text {th }}$ group, to the $60^{\text {th }}-80^{\text {th }}$ group and to the highest $20^{\text {th }}$ percentile, though with different significance levels. As showed in the table, a ten percent cut in wages results in $0.54 \%$ increase in working hours for the poorest group. As the wealth level increase to the next threshold, a ten percent drop in wages results in an increase in working hours by $0.49 \%$. The group which is considered the richest (for the purpose of this study) still does not cut much of their outside work hours. They increase their working hours by $0.39 \%$ if wages decline by ten percent. Put it differently, results of this study points to a negative labor supply elasticity that drops as the well being of households increases. This range of elasticities is comparable to Dessing (2003) estimates.

These results support the previous claim that poor households depend on secondary workers, who are women most of the time, to satisfy their basic needs. Once these needs are met, women cut back on their outside labor and free some of their time to enhance the welfare of the family by taking care of the domestic chores.

Table (4) also shows age is a factor in determining hours supplied, even after wage is considered, suggesting a life cycle role in this model. Workers with different levels of education appear to respond differently to a $10 \%$ drop in wages. Those with secondary education increase their work hours by a range of $0.34-0.63 \%$. Whereas university educated workers increase their working hours by a range of $0.12-0.70 \%$ depending on their wealth status.

Holding wages constant, the availability of, and probably access to, other men's earnings as well as having children either in the $0-2$ or the 3-6 age groups does not have any significant effect on hours of work.

That means they have the opportunity to invest in training and education. However, these women find it difficult to perform either because of lack of time and funds. Provision of such training programs is essential for breaking the cycle at this stage. Introducing these programs must be accompanied by providing simultaneous programs aiming at reducing domestic work and provision of day care, for these programs to be successful. 
Halting public sector hiring of graduates in Egypt in the 1990s, which further worsened employment opportunities, is likely to have had a conflicting impact on women's labor supply, on the one hand by depressing the wage offered to women's new entrants, on the other hand queuing in unemployment lines. In a study on women workers of Buenos Aires, Cerrutti M. (2000) found that most of women's labor force participation growth has been in the self-employment sector, a result of falling job opportunities and labor conditions, and increasing levels of employment instability and unemployment among men primary earners. The same story may well be valid here, until further research. Will self-employment increase the men/women's earnings inequality or raise the relative economic status of women? Programs aiding women to setup their income-generating activities represent only one step in that direction.

Finally, policies should aim at promoting the available natural gift by promoting labor demand industries that make extensive use of women labor. Industries that are exportoriented, or labor-intensive manufacturing, may well create the base for such course of action.

\section{Table (4): Log Hours Equations: Self Employed + Private Wage Workers}

\begin{tabular}{|c|c|c|c|c|c|}
\hline Variables & $\begin{array}{l}\text { Model (1) } \\
\text { Below 20 } \\
\text { Percentile }\end{array}$ & $\begin{array}{l}\text { Model (2) } \\
20^{\text {th}}-40^{\text {th }} \\
\text { Percentile }\end{array}$ & $\begin{array}{l}\text { Model (3) } \\
40^{\text {th }}-60^{\text {th }} \\
\text { Percentile }\end{array}$ & $\begin{array}{l}\text { Model (4) } \\
60^{\text {th }}-80^{\text {th }} \\
\text { Percentile }\end{array}$ & $\begin{array}{l}\text { Model (5) } \\
\text { 80 }^{\text {th}}-100^{\text {th }} \\
\text { Percentile }\end{array}$ \\
\hline Predicted Log Wage & $-0.541^{*}$ & $-0.488^{* *}$ & $\begin{array}{l}-0.377 \\
(0.154)\end{array}$ & $-0.337+$ & $-0.392 * *$ \\
\hline Age & $-0.157 * *$ & $-0.152 * *$ & $\begin{array}{l}0.034 \\
(0.066)\end{array}$ & $0.168^{* *}$ & $-0.155^{* *}$ \\
\hline Age2 & $\begin{array}{l}0.075 \\
(0.045)\end{array}$ & $\begin{array}{l}0.084 \\
(0.064)\end{array}$ & $\begin{array}{l}-0.084 \\
(0.062)\end{array}$ & $\begin{array}{l}-0.202^{*} \\
(0.093)\end{array}$ & $\begin{array}{l}0.083 \\
(0.064)\end{array}$ \\
\hline Ability To Read \&Write & $\begin{array}{l}-1.137 * * \\
(0.307)\end{array}$ & $\begin{array}{l}-0.082 \\
(0.333)\end{array}$ & $\begin{array}{l}0.000 \\
(0.000)\end{array}$ & $\begin{array}{l}-0.692 \\
(0.545)\end{array}$ & $\begin{array}{l}-0.376 \\
(0.461)\end{array}$ \\
\hline Primary & $\begin{array}{l}-0.380 \\
(0.277)\end{array}$ & $\begin{array}{l}-0.205 \\
(0.247)\end{array}$ & $\begin{array}{l}-0.042 \\
(0.450)\end{array}$ & $\begin{array}{l}-0.247 \\
(0.538)\end{array}$ & $\begin{array}{l}-0.771 \\
(0.494)\end{array}$ \\
\hline Preparatory & $\begin{array}{l}-1.652 * * \\
(0.398)\end{array}$ & $\begin{array}{l}-0.318 \\
(0.524)\end{array}$ & $\begin{array}{l}-0.387 \\
(0.567)\end{array}$ & $\begin{array}{l}0.000 \\
(0.000)\end{array}$ & $\begin{array}{l}-0.516 \\
(0.720)\end{array}$ \\
\hline Secondary & $\begin{array}{l}-0.530 * * \\
(0.000)\end{array}$ & $\begin{array}{l}-0.340 * * \\
(0.000)\end{array}$ & $\begin{array}{l}-0.535^{* *} \\
(0.006)\end{array}$ & $\begin{array}{l}-0.632 * \\
(0.393)\end{array}$ & $\begin{array}{l}-0.532 \\
(0.420)\end{array}$ \\
\hline University & $\begin{array}{l}-0.350+ \\
(0.192)\end{array}$ & $\begin{array}{l}-0.306+ \\
(0.164)\end{array}$ & $\begin{array}{l}-0.669+ \\
(0.347)\end{array}$ & $\begin{array}{l}-0.127 * * \\
(0.001)\end{array}$ & $\begin{array}{l}-0.711^{*} \\
(0.343)\end{array}$ \\
\hline Post Graduate & $\begin{array}{l}-0.197 \\
(0.396)\end{array}$ & $\begin{array}{l}0.119 \\
(0.398)\end{array}$ & $\begin{array}{l}-0.295 \\
(0.340)\end{array}$ & $\begin{array}{l}-0.018 \\
(0.303)\end{array}$ & $\begin{array}{l}-0.264 \\
(0.397)\end{array}$ \\
\hline No. of Children 0-2 & $\begin{array}{l}-0.037 \\
(0.222)\end{array}$ & $\begin{array}{l}-0.292 \\
(0.226)\end{array}$ & $\begin{array}{l}-0.115 \\
(0.240)\end{array}$ & $\begin{array}{l}-0.398 \\
(0.528)\end{array}$ & $\begin{array}{l}-0.122 \\
(0.260)\end{array}$ \\
\hline No. of Children 3-6 & $\begin{array}{l}-0.336+ \\
(0.177)\end{array}$ & $\begin{array}{l}0.210 \\
(0.235)\end{array}$ & $\begin{array}{l}-0.168 \\
(0.264)\end{array}$ & $\begin{array}{l}-0.230 \\
(0.254)\end{array}$ & $\begin{array}{l}0.261 \\
(0.218)\end{array}$ \\
\hline Log HH Male Earnings & $\begin{array}{l}0.031 \\
(0.036)\end{array}$ & $\begin{array}{l}0.024 \\
(0.033)\end{array}$ & $\begin{array}{l}0.044 \\
(0.046)\end{array}$ & $\begin{array}{l}0.083 \\
(0.050)\end{array}$ & $\begin{array}{l}0.070+ \\
(0.037)\end{array}$ \\
\hline Lambda & $\begin{array}{l}-2.140 \\
(4.085)\end{array}$ & $\begin{array}{l}-0.939 \\
(5.306)\end{array}$ & $\begin{array}{l}2.559 \\
(4.233)\end{array}$ & $\begin{array}{l}8.339 \\
(5.656)\end{array}$ & $\begin{array}{l}6.111 \\
(4.841)\end{array}$ \\
\hline Constant & $\begin{array}{l}8.696 * * \\
(0.664)\end{array}$ & $\begin{array}{l}8.214 * * \\
(0.970)\end{array}$ & $\begin{array}{l}7.773 * * \\
(0.974)\end{array}$ & $\begin{array}{l}4.133^{*} \\
(1.546)\end{array}$ & $\begin{array}{l}8.471 * * \\
(1.091)\end{array}$ \\
\hline No. of Observations & 69 & 63 & 34 & 34 & 62 \\
\hline R-squared & 0.27 & 0.36 & 0.36 & 0.28 & 0.39 \\
\hline
\end{tabular}

Source: Author's calculations; ELMS (1998)

Standard errors in parentheses

+ significant at $10 \% ; *$ significant at $5 \% ; * *$ significant at $1 \%$ 
Two general comments on Table (4): first, the low $R 2$-values imply there is still a wide range of unidentified determinants explaining the decision to work extra hours or not. Second, these results suggest the category of 15-64 years is a diverse of a group to have one labor supply function. Thus, an analysis of the determinants of labor supply using a disaggregated database should be the focus of further empirical investigations.

\section{Conclusion}

Unlike what the classical theory of labor supply claims of positive elasticity at low levels of income (or wages), the analysis in this study found no evidence of such claim. At low income levels, or below some threshold, economic hardships are likely to press women to work longer hours to overcome their economic hardships. At the same time, they are responsible for home activities and child care. Thus, it is expected to get a negative elasticity for this sub-sample. At the same time, these women are responsible for home activities and child care. That's probably why when conditions improve they withdraw from the labor market or work fewer hours. At higher levels of income, women transfer some or all of household activities to domestic laborer and join the labor market producing, again, negative elasticities.

The negative labor supply schedule points to the need to limit exploiting workers at low wage rates and calls for imposing, and enforcing, minimum wage legislation. Yet the lower work hours at intermediate and high wealth levels is a sign of a sigh of relief from the subsistence trap. During that time, women improve the welfare of their families by reducing their hours of work outside the house. 
Table (A-1): Scoring Coefficients, Mean and Standard Deviation of Assets Comprising the Wealth Factor In Urban Egypt, 1998

\begin{tabular}{|c|c|c|c|c|}
\hline Variable* & Scoring Coefficient & Mean & Std. Dev. & Coefficient/SD \\
\hline Quality of Walls & 0.023 & 0.754 & 0.43 & 0.053 \\
\hline Quality of floor & 0.072 & 0.899 & 0.301 & 0.239 \\
\hline Quality of roof & 0.071 & 0.837 & 0.37 & 0.192 \\
\hline Access to Piped water & 0.032 & 0.978 & 0.148 & 0.216 \\
\hline Availability of Waste Collection Services & 0.05 & 0.366 & 0.482 & 0.104 \\
\hline Own a Phone & 0.109 & 0.455 & 0.498 & 0.219 \\
\hline Connected to Sewer/Septic Tank** & 0.055 & 1.733 & 0.524 & 0.105 \\
\hline Access to Electricity & 0.015 & 0.995 & 0.072 & 0.208 \\
\hline Interest or Income From Dividends & 0.027 & 0.032 & 0.175 & 0.154 \\
\hline Own a Fridge & 0.123 & 0.847 & 0.36 & 0.342 \\
\hline Own a Freezer & 0.037 & 0.06 & 0.238 & 0.155 \\
\hline Own a Dishwasher & 0.017 & 0.021 & 0.144 & 0.118 \\
\hline Own a Colored TV & 0.15 & 0.726 & 0.446 & 0.336 \\
\hline Own a B\&W TV & -0.051 & 0.309 & 0.462 & -0.110 \\
\hline Own a Video & 0.065 & 0.182 & 0.386 & 0.168 \\
\hline Own an Air Condition & 0.035 & 0.043 & 0.203 & 0.172 \\
\hline Own a Microwave & 0.008 & 0.015 & 0.123 & 0.065 \\
\hline Own a Gas Stove & 0.086 & 0.83 & 0.375 & 0.229 \\
\hline Own a Kerosene Stove & -0.058 & 0.474 & 0.499 & -0.116 \\
\hline Own an Electric Fan & 0.082 & 0.762 & 0.426 & 0.192 \\
\hline Own a Water Heater & 0.144 & 0.475 & 0.499 & 0.289 \\
\hline Own a Space Heater & 0.044 & 0.082 & 0.275 & 0.160 \\
\hline Own a Sewing Machine & 0.037 & 0.222 & 0.416 & 0.089 \\
\hline Own an Iron & 0.118 & 0.768 & 0.422 & 0.280 \\
\hline Own a Radio & 0.062 & 0.815 & 0.388 & 0.160 \\
\hline Own a Washing Machine & 0.069 & 0.918 & 0.274 & 0.252 \\
\hline Own a Camera & 0.054 & 0.146 & 0.353 & 0.153 \\
\hline Own a Bicycle & 0.021 & 0.221 & 0.415 & 0.051 \\
\hline Own a Scooter & 0.004 & 0.02 & 0.142 & 0.028 \\
\hline Own a Car & 0.051 & 0.089 & 0.285 & 0.179 \\
\hline Own a Taxi & 0.006 & 0.009 & 0.097 & 0.062 \\
\hline Own a Van & 0.008 & 0.014 & 0.116 & 0.069 \\
\hline No. of Rooms $* * *$ & 0.035 & 3.74 & 1.307 & 0.027 \\
\hline
\end{tabular}

Source: Author's calculations; ELMS (1998)

*All variables are binary $(0,1)$ except otherwise indicated.

**Takes the value 2 if connected to public sewer, value 1 If connected to septic tank, and zero otherwise

**No. of rooms ranges from 1 to 12 
Table (A-2): Means of Assets Included in First Principal Component According to Cut Off Points For Private Wage and Self Employed Workers

\begin{tabular}{|c|c|c|c|c|c|}
\hline Variables* & $\begin{array}{l}\text { Below 20 } \\
\text { Percentile }\end{array}$ & $\begin{array}{l}20^{\text {th }}-40^{\text {th }} \\
\text { Percentile }\end{array}$ & $\begin{array}{l}40^{\text {th }}-60^{\text {th }} \\
\text { Percentile }\end{array}$ & $\begin{array}{l}60^{\text {th }}-80^{\text {th }} \\
\text { Percentile }\end{array}$ & $\begin{array}{l}80^{\text {th }}-100^{\text {th }} \\
\text { Percentile }\end{array}$ \\
\hline Quality of Walls & 0.681 & 0.817 & 0.882 & 0.871 & 0.958 \\
\hline Quality of floor & 0.609 & 0.933 & 0.971 & 0.968 & 1.000 \\
\hline Quality of roof & 0.507 & 0.800 & 0.971 & 0.968 & 1.000 \\
\hline Access to Piped water & 0.913 & 0.983 & 1.000 & 1.000 & 1.000 \\
\hline Availability of Waste Collection Serv. & 0.203 & 0.383 & 0.441 & 0.645 & 0.833 \\
\hline Own a Phone & 0.014 & 0.167 & 0.176 & 0.742 & 1.000 \\
\hline Connected to Sewer/Septic Tank** & 1.493 & 1.600 & 1.647 & 1.935 & 2.000 \\
\hline Access to Electricity & 0.957 & 1.000 & 1.000 & 1.000 & 1.000 \\
\hline Interest or Income From Dividends & 0.000 & 0.000 & 0.000 & 0.000 & 0.000 \\
\hline Own a Fridge & 0.304 & 0.833 & 1.000 & 1.000 & 1.000 \\
\hline Own a Freezer & 0.000 & 0.000 & 0.059 & 0.032 & 0.125 \\
\hline Own a Dishwasher & 0.000 & 0.017 & 0.000 & 0.000 & 0.000 \\
\hline Own a Colored TV & 0.116 & 0.633 & 0.853 & 1.000 & 1.000 \\
\hline Own a B\&W TV & 0.667 & 0.517 & 0.235 & 0.097 & 0.083 \\
\hline Own a Video & 0.000 & 0.067 & 0.029 & 0.161 & 0.417 \\
\hline Own an Air Condition & 0.000 & 0.000 & 0.000 & 0.000 & 0.042 \\
\hline Own a Microwave & 0.000 & 0.017 & 0.000 & 0.000 & 0.000 \\
\hline Own a Gas Stove & 0.362 & 0.867 & 0.971 & 0.935 & 1.000 \\
\hline Own a Kerosene Stove & 0.841 & 0.583 & 0.324 & 0.323 & 0.083 \\
\hline Own an Electric Fan & 0.449 & 0.633 & 0.941 & 0.935 & 1.000 \\
\hline Own a Water Heater & 0.000 & 0.067 & 0.412 & 0.839 & 0.958 \\
\hline Own a Space Heater & 0.000 & 0.000 & 0.059 & 0.097 & 0.208 \\
\hline Own a Sewing Machine & 0.101 & 0.183 & 0.176 & 0.258 & 0.542 \\
\hline Own an Iron & 0.203 & 0.733 & 0.971 & 1.000 & 1.000 \\
\hline Own a Radio & 0.565 & 0.717 & 0.971 & 0.935 & 0.958 \\
\hline Own a Washing Machine & 0.667 & 0.967 & 0.971 & 0.968 & 0.958 \\
\hline Own a Camera & 0.000 & 0.000 & 0.029 & 0.129 & 0.208 \\
\hline Own a Bicycle & 0.087 & 0.083 & 0.235 & 0.258 & 0.000 \\
\hline Own a Scooter & 0.029 & 0.000 & 0.029 & 0.032 & 0.042 \\
\hline Own a Car & 0.000 & 0.000 & 0.000 & 0.032 & 0.208 \\
\hline Own a Taxi & 0.000 & 0.017 & 0.000 & 0.000 & 0.042 \\
\hline Own a Van & 0.000 & 0.000 & 0.000 & 0.032 & 0.000 \\
\hline No. of Rooms ${ }^{* * *}$ & 2.942 & 3.133 & 3.088 & 3.645 & 4.000 \\
\hline Overall Mean & -1.482 & -0.408 & 0.155 & 0.580 & 0.921 \\
\hline No. of Observations & 69 & 63 & 34 & 34 & 62 \\
\hline
\end{tabular}

Source: Author's calculations; ELMS (1998)

*All variables are binary $(0,1)$ except otherwise indicated.

**Takes the value 2 if connected to public sewer, value 1 If connected to septic tank, and zero otherwise

**No. of rooms ranges from 1 to 12 
Table (A-3): Means and Standard Deviations of Variables Used in the Analysis, Total Sample, Urban Women 16-64, Egypt 1998

\begin{tabular}{|c|c|c|c|c|c|c|c|c|c|c|c|c|}
\hline Variables & $\begin{array}{l}\text { Total } \\
\text { Mean }\end{array}$ & $\begin{array}{l}\text { ample } \\
\text { Std Dev. }\end{array}$ & $\begin{array}{l}<\mathbf{2 0}^{\text {th }} \\
\text { Mean }\end{array}$ & $\begin{array}{l}\text { Percentile } \\
\text { Std Dev. }\end{array}$ & $\begin{array}{l}20^{\text {th }}-40^{\text {th }} \\
\text { Mean }\end{array}$ & $\begin{array}{l}\text { Percentile } \\
\text { Std Dev. }\end{array}$ & 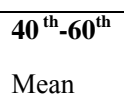 & $\begin{array}{l}\text { Percentile } \\
\text { Std Dev. }\end{array}$ & $\begin{array}{l}\mathbf{6 0}^{\text {th }}-\mathbf{8 0}^{\text {th }} \\
\text { Mean }\end{array}$ & $\begin{array}{l}\text { Percentile } \\
\text { Std Dev. }\end{array}$ & $\begin{array}{l}\mathbf{8 0}^{\text {th }} \mathbf{- 1 0 0 ^ { \text { th } }} \\
\text { Mean }\end{array}$ & $\begin{array}{l}\text { Percentile } \\
\text { Std Dev. }\end{array}$ \\
\hline Log Hourly Wage & 7.55 & 0.63 & 7.57 & 0.76 & 7.56 & 0.64 & 7.62 & 0.52 & 7.49 & 0.57 & 7.57 & 0.44 \\
\hline Log Yearly Hours & 0.13 & 0.83 & -0.25 & 0.46 & -0.14 & 0.50 & 0.00 & 0.85 & 0.28 & 0.80 & 0.40 & 0.62 \\
\hline Age & 34.47 & 12.20 & 33.31 & 13.24 & 35.20 & 12.88 & 30.26 & 10.48 & 33.90 & 10.66 & 33.67 & 11.84 \\
\hline Experience & 19.85 & 13.66 & 19.50 & 14.82 & 20.66 & 15.00 & 14.05 & 12.70 & 18.44 & 11.85 & 19.50 & 12.69 \\
\hline Illiterate (Reference) & 0.28 & 0.45 & 0.56 & 0.50 & 0.43 & 0.50 & 0.21 & 0.41 & 0.12 & 0.32 & 0.03 & 0.18 \\
\hline Read\&Write & 0.04 & 0.21 & 0.07 & 0.26 & 0.06 & 0.24 & 0.00 & 0.00 & 0.02 & 0.14 & 0.07 & 0.25 \\
\hline Primary & 0.07 & 0.26 & 0.10 & 0.30 & 0.14 & 0.35 & 0.05 & 0.23 & 0.02 & 0.14 & 0.13 & 0.35 \\
\hline Preparatory & 0.04 & 0.19 & 0.04 & 0.20 & 0.03 & 0.17 & 0.05 & 0.23 & 0.06 & 0.24 & 0.03 & 0.18 \\
\hline General Secondary & 0.02 & 0.14 & 0.00 & 0.00 & 0.02 & 0.12 & 0.05 & 0.23 & 0.06 & 0.24 & 0.00 & 0.00 \\
\hline University & 0.26 & 0.44 & 0.19 & 0.40 & 0.26 & 0.44 & 0.42 & 0.50 & 0.31 & 0.47 & 0.23 & 0.43 \\
\hline Post Graduate & 0.28 & 0.45 & 0.04 & 0.20 & 0.06 & 0.24 & 0.21 & 0.41 & 0.42 & 0.50 & 0.50 & 0.51 \\
\hline Greater Cairo(Referene) & 0.45 & 0.50 & 0.15 & 0.36 & 0.32 & 0.47 & 0.42 & 0.50 & 0.50 & 0.50 & 0.80 & 0.41 \\
\hline Alex.\&Sz Cnl. & 0.16 & 0.37 & 0.14 & 0.35 & 0.22 & 0.41 & 0.16 & 0.37 & 0.21 & 0.41 & 0.10 & 0.31 \\
\hline Lower Urban Egypt & 0.20 & 0.40 & 0.31 & 0.46 & 0.29 & 0.46 & 0.29 & 0.46 & 0.15 & 0.36 & 0.03 & 0.18 \\
\hline Upper Urban Egypt & 0.19 & 0.39 & 0.40 & 0.49 & 0.17 & 0.38 & 0.13 & 0.34 & 0.13 & 0.34 & 0.07 & 0.25 \\
\hline No. of Children 0-2 & 0.16 & 0.37 & 0.15 & 0.36 & 0.18 & 0.39 & 0.26 & 0.45 & 0.13 & 0.34 & 0.03 & 0.18 \\
\hline No. of Children 3-6 & 0.24 & 0.43 & 0.29 & 0.46 & 0.17 & 0.38 & 0.32 & 0.47 & 0.27 & 0.45 & 0.13 & 0.35 \\
\hline Log other Men's Earnings & 3.50 & 2.87 & 3.12 & 2.65 & 3.26 & 2.71 & 3.75 & 2.78 & 3.87 & 2.91 & 4.32 & 2.95 \\
\hline No. of Observations & 312 & & 72 & & 65 & & 38 & & 52 & & 85 & \\
\hline
\end{tabular}

Source: Authour's calculations; ELMS (1998) 
Table (A-4): Log Hours Equations: Self Employed + Public and Private Wage Workers

\begin{tabular}{|c|c|c|c|c|c|}
\hline Variables & $\begin{array}{l}\text { Model (1) } \\
\text { Below 20 } \\
\text { Percentile } \\
\end{array}$ & $\begin{array}{l}\text { Model (2) } \\
20^{\text {th }}-40^{\text {th }} \\
\text { Percentile }\end{array}$ & $\begin{array}{l}\text { Model (3) } \\
40^{\text {th }}-60^{\text {th }} \\
\text { Percentile }\end{array}$ & $\begin{array}{l}\text { Model (4) } \\
60^{\text {th }}-80^{\text {th }} \\
\text { Percentile }\end{array}$ & $\begin{array}{l}\text { Model (5) } \\
80^{\text {th }}-100^{\text {th }} \\
\text { Percentile }\end{array}$ \\
\hline Predicted Log Wage & $-0.534 * *$ & $-0.494 * *$ & -0.384 & $-0.348 *$ & $-0.377 * *$ \\
\hline & $(0.201)$ & $(0.171)$ & $(0.125)$ & $(0.110)$ & $(0.067)$ \\
\hline Age & $-0.139 * *$ & $-0.130 *$ & 0.036 & $0.129 * *$ & $0.107 * *$ \\
\hline & $(0.035)$ & $(0.070)$ & $(0.041)$ & $(0.045)$ & $(0.039)$ \\
\hline Age2 & 0.056 & 0.054 & -0.088 & -0.029 & 0.007 \\
\hline & $(0.046)$ & $(0.064)$ & $(0.057)$ & $(0.055)$ & $(0.048)$ \\
\hline Ability To Read \&Write & $-1.079 * *$ & -0.006 & 0.000 & -0.294 & -0.483 \\
\hline & $(0.318)$ & $(0.343)$ & $(0.000)$ & $(0.501)$ & $(0.401)$ \\
\hline Primary & $\begin{array}{l}-0.256 \\
(0.282)\end{array}$ & $\begin{array}{l}-0.187 \\
(0.256)\end{array}$ & $\begin{array}{l}-0.001 \\
(0.414)\end{array}$ & $\begin{array}{l}-0.419 \\
(0.504)\end{array}$ & $\begin{array}{c}-0.835+ \\
(0.422)\end{array}$ \\
\hline Preparatory & $\begin{array}{l}-1.543 * * \\
(0.411)\end{array}$ & $\begin{array}{l}-0.253 \\
(0.539)\end{array}$ & $\begin{array}{l}-0.470 \\
(0.420)\end{array}$ & $\begin{array}{l}-0.012 \\
(0.332)\end{array}$ & $\begin{array}{l}-0.499 \\
(0.506)\end{array}$ \\
\hline Secondary & $\begin{array}{l}-0.533 * * \\
(0.032)\end{array}$ & $\begin{array}{l}-0.250 * * \\
(0.048)\end{array}$ & $\begin{array}{l}-0.378^{*} \\
(0.178)\end{array}$ & $\begin{array}{l}-0.360^{*} \\
(0.056)\end{array}$ & $\begin{array}{l}-0.059 \\
(0.440)\end{array}$ \\
\hline University & $\begin{array}{l}-0.127 * * \\
(0.061)\end{array}$ & $\begin{array}{l}-0.273+ \\
(0.158)\end{array}$ & $\begin{array}{l}-0.630+ \\
(0.307)\end{array}$ & $\begin{array}{l}0.264+ \\
(0.145)\end{array}$ & $\begin{array}{l}-0.500^{*} \\
(0.251)\end{array}$ \\
\hline Post Graduate & $\begin{array}{l}-0.039 \\
(0.404)\end{array}$ & $\begin{array}{l}-0.254 \\
(0.383)\end{array}$ & $\begin{array}{l}-0.337 \\
(0.299)\end{array}$ & $\begin{array}{l}-0.068 \\
(0.243)\end{array}$ & $\begin{array}{l}-0.302 \\
(0.342)\end{array}$ \\
\hline No. of Children 0-2 & $\begin{array}{l}-0.184 \\
(0.223)\end{array}$ & $\begin{array}{l}-0.412+ \\
(0.224)\end{array}$ & $\begin{array}{l}-0.012 \\
(0.205)\end{array}$ & $\begin{array}{l}-0.855^{* *} \\
(0.236)\end{array}$ & $\begin{array}{l}-0.053 \\
(0.204)\end{array}$ \\
\hline No. of Children 3-6 & $\begin{array}{l}-0.242 \\
(0.180)\end{array}$ & $\begin{array}{l}0.053 \\
(0.235)\end{array}$ & $\begin{array}{l}-0.092 \\
(0.220)\end{array}$ & $\begin{array}{l}-0.143 \\
(0.164)\end{array}$ & $\begin{array}{l}0.125 \\
(0.166)\end{array}$ \\
\hline Log HH Male Earnings & $\begin{array}{l}0.019 \\
(0.036)\end{array}$ & $\begin{array}{l}0.022 \\
(0.034)\end{array}$ & $\begin{array}{l}0.035 \\
(0.040)\end{array}$ & $\begin{array}{l}-0.007 \\
(0.027)\end{array}$ & $\begin{array}{l}0.059^{*} \\
(0.026)\end{array}$ \\
\hline Lambda & $\begin{array}{l}-2.292 \\
(4.201)\end{array}$ & $\begin{array}{l}-1.341 \\
(5.505)\end{array}$ & $\begin{array}{l}2.695 \\
(3.917)\end{array}$ & $\begin{array}{l}1.211 \\
(4.126)\end{array}$ & $\begin{array}{l}6.422 \\
(3.920)\end{array}$ \\
\hline Constant & $\begin{array}{l}8.263 * * \\
(0.668)\end{array}$ & $\begin{array}{l}7.907 * * \\
(0.974)\end{array}$ & $\begin{array}{l}7.721^{* *} \\
(0.852)\end{array}$ & $\begin{array}{l}7.122^{* *} \\
(0.932)\end{array}$ & $\begin{array}{l}7.441 * * \\
(0.835)\end{array}$ \\
\hline No. of Observations & 72 & 65 & 38 & 52 & 85 \\
\hline R-squared & 0.32 & 0.28 & 0.35 & 0.34 & 0.25 \\
\hline
\end{tabular}

Source: Author's calculations; ELMS (1998)

Standard errors in parentheses

+ significant at $10 \% ; *$ significant at $5 \% ; * *$ significant at $1 \%$ 
Figure A-1: Average Hourly Wages by Wealth Index and Type of Employment Urban Women 15-64, Egypt 1998

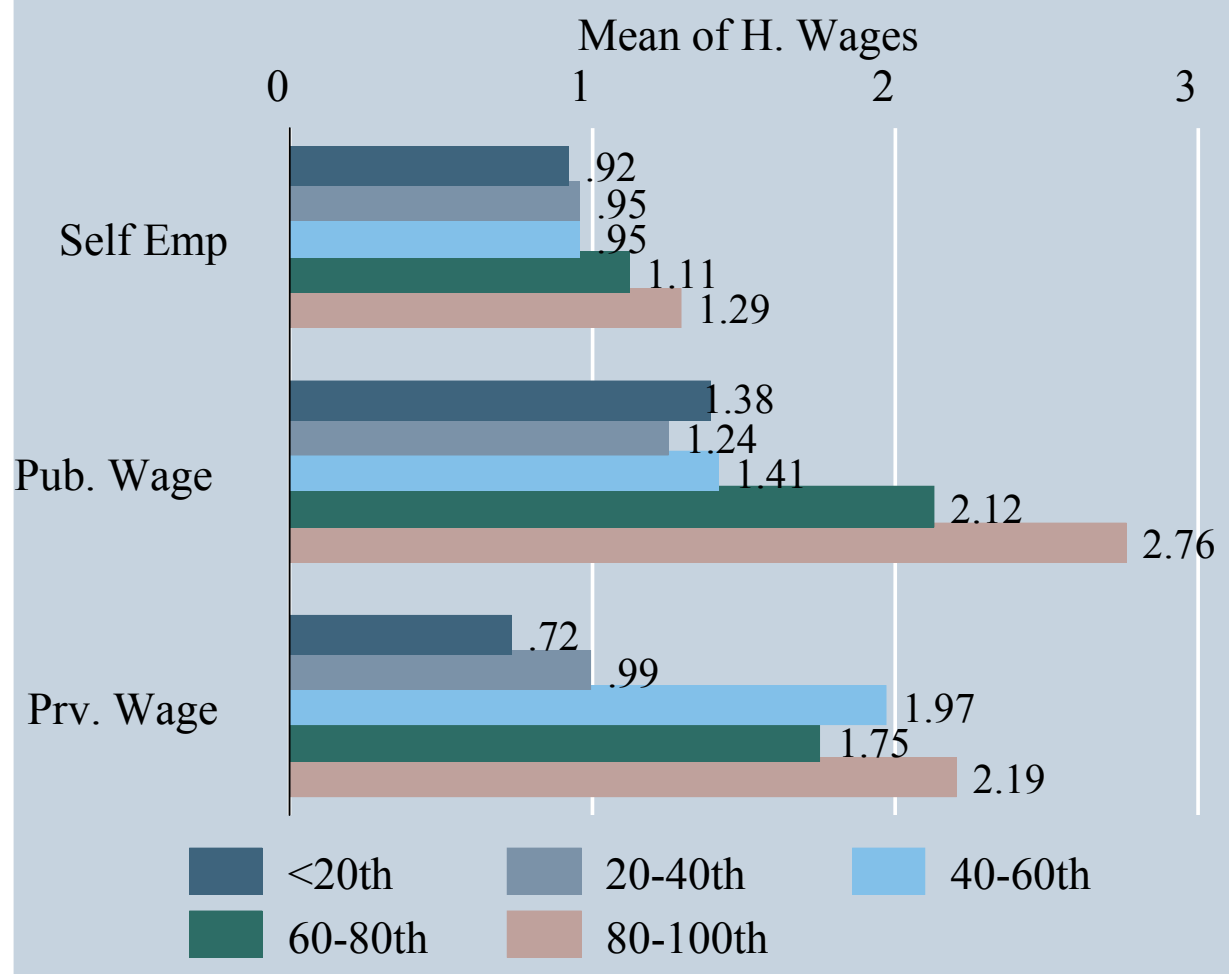




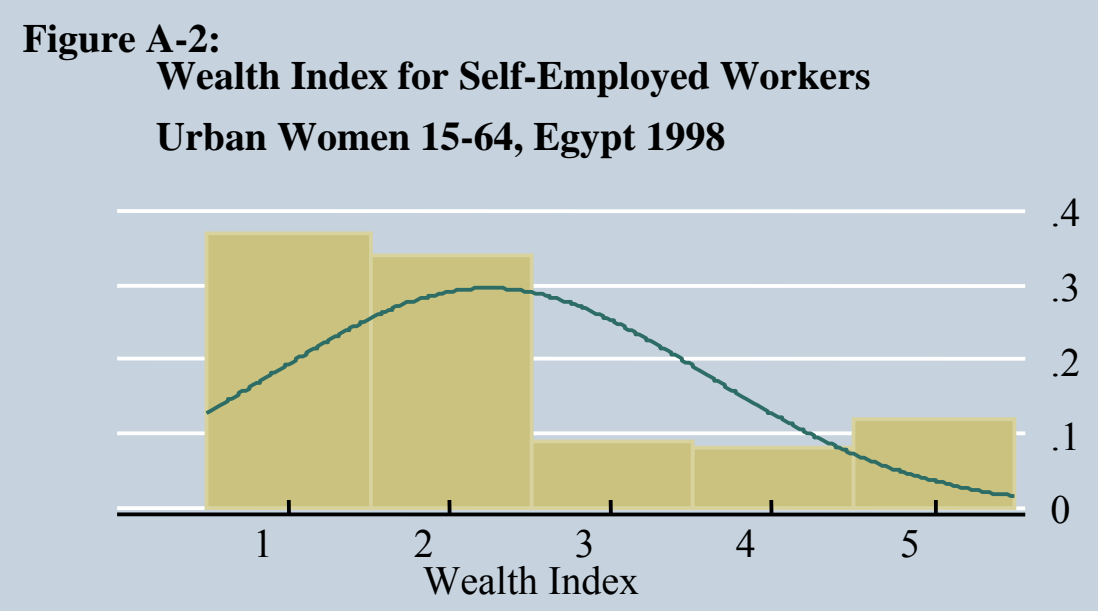

\section{Wealth Index for Private Wage Workers}

Urban Women 15-64, Egypt 1998

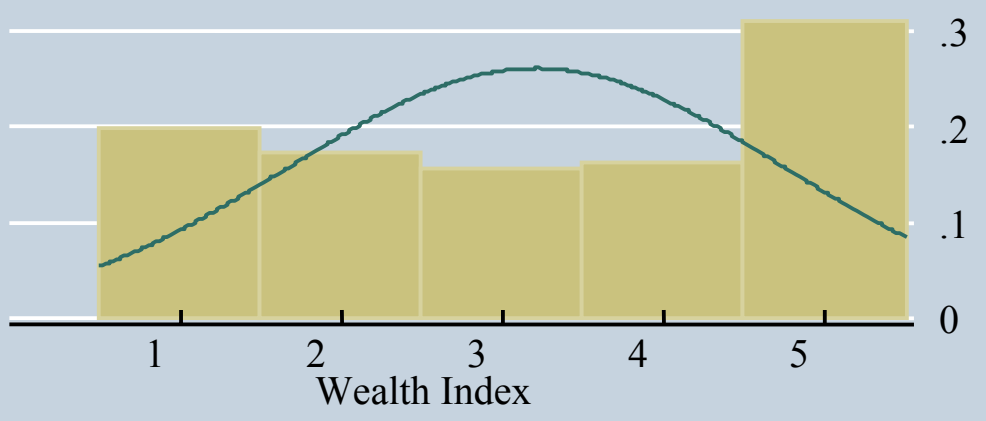

\section{Wealth Index for All Workers}

Urban Women 15-64, Egypt 1998

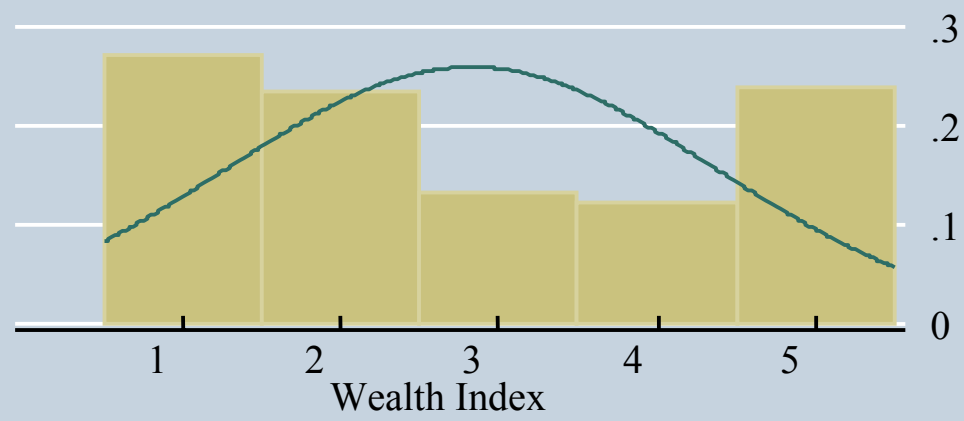

Density

\begin{tabular}{|ll|}
\hline 1 & $<20^{\text {th }}$ Percentile \\
2 & $20^{\text {th }}-40^{\text {th }}$ Percentile \\
3 & $40^{\text {th }}-60^{\text {th }}$ Percentile \\
4 & $60^{\text {th }}-80^{\text {th }}$ Percentile \\
5 & Highest $20^{\text {th }}$ Percentile \\
\hline
\end{tabular}




\section{$\underline{\text { References }}$}

Anker, Richard (1990). "Methodological Considerations in Measuring Women's Labor Force Activity in Developing Countries: The Case of Egypt." In Research in Human Capital and Development, Ismail Serageldin (ed.), vol. 6: 26-58. Greenwich: JAI Press.

Assaad, R. and Fatma El-Hamidi (2002). ""Female Labor Supply in Egypt: Participation and Hours of Work". In Human Capital: Population Economics In The Middle East. Ismail Sirageldin (ed.) Cairo: American University in Cairo Press, pp. 210230.

Assaad, R. (2002). “The Transformation of the Egyptian Labor Market: 1988-1998”. Unpublished paper.

Assaad, R., Levison, Deborah; and Zibani, Nadia. (2003). "The effect of child work on schooling in Egypt”. Unpublished paper.

Assaad, R. and Zouari, S. (2003). "Female Labor Force Participation, Fertility and the Timing of Marriage in Morocco". Paper Presented at the Anuual Meeting of the Middle East Economic Association (MEEA), in Collaboration with the Allied Social Science Associations (ASSA). Washington, D.C. January 2-5, 2003.

Assaad, R. (1997a). "The employment crisis in Egypt: Current trends and future prospects." In Research in Middle East Economics, Vol. 2, pp39-66. Greenwich: JAI Press.

Assaad, Ragui. (1997b). "The effects of public sector hiring and compensation policies on the Egyptian labor market." World Bank Economic Review 11(1).

Babb, F. E. (1990). "Women and work in Latin America". Latin American Research Review, 25(2), pp 236-247.

Barzel, Y., McDonald, R.J. (1973). "Assets, subsistence and the supply curve of labor. American Economy Review. Vol. 63 (Sept), pp 621-633.

Bates, T. (1997). Race, Self-Employment, and Upward Mobility. Baltimore: The Johns Hopkins Press.

Berg, E. J., (1961). "Backward - sloping labor supply functions in dual economies: the Africa Case”. Quarterly Journal of Economics. Vol (75), pp 468-514.

Blau, D. (1985). "Self-employment and self-selection in developing country labor markets". Southern Economic Journal 52(4) pp 351-63.

Blau, D. (1987). "A time-series analysis of self-employment in the United States". Journal of Political Economy 95(3) pp 445-467.

Borjas, G., and Bronars, S. (1989). "Consumer discrimination and self-employment". Journal of Political Economy 97(3) pp 581-605. 
Catsiapis G. and C. Robinson (1982). "Sample selection bias with multiple selection rules". Journal of Econometrics, 18,pp 351-368.

Cerrutti, Marcela (2000). "Economic reform, structural adjustment and female labor force participation in Buenos Aires, Argentina". World Development. Vol. 28, No. 5, pp879-891.

Connelly, R., D. DeGraff, and D. Levison. (1996). "Women's employment and child care in Brazil." Economic Development and Cultural Change 44(3) pp 619-56.

Datt, G., and D. Jolliffe, (1998). "Poverty in Egypt: Modeling and policy simulations". Mimeo, IFPRI, Washington, D.C.

Dessing, Maryke. (2002). "Labor supply, the family and poverty: the S-shaped labor supply curve". Journal of Economic Behavior and Organization, Vol. 49, pp433458.

Devine, T. (1994a). "Characteristics of self-employed women in the United States". Monthly Labor Review. March pp 20-34.

Devine, T. (1994b). "Changes in wage-and-salary returns to skill and the recent rise in female self-employment”. American Economic Review 84(2) pp108-113.

Dixon-Muller, R., and R. Anker. (1988). Assessing Women's Economic Contribution To Development. Geneva: ILO.

Eberharter, Veronica. (2001). "Gender roles, labor market participation, and household income position”. Structural Change and Economic Dynamics, Vol. 12, pp 235246.

El-Hamidi, Fatma. (2003). "Labor supply of Egyptian married women: participation and hours of work". Paper presented at the Annual Meeting of the Middle East Economic Association (MEEA) and Allied Social Science Association (ASSA). January 2-5, 2003. Washington, D.C.

El-Laithy, Heba; Lokshin, Michael; and Banerji Arup. (2003). "Poverty and economic growth in Egypt. World Bank Policy Research Working Paper No. 3068.

Eltigani, Eltahir. (1990). "The Mode of agricultural production and female labor force participation: The case of Gezira Scheme, Sudan". Research in Human Capital and Development, Ismail Serageldin (ed.), vol. 6 pp 247-268.

Evans, D., and Jovanovic, B. (1989). "An estimated model of entrepreneurial choice under liquidity constraints”. Journal of Political Economy 97(4), pp 808-827.

Evans, D., and Leighton, L. (1989). "Some empirical aspects of entrepreneurship". American Economic Review 79(3) pp 519-535.

Fairlie, R., and Meyer, B. (1996). "Ethnic and racial self-employment differences and possible explanations". Journal of Human Resources 31(4) pp 757-793. 
Filmer, Deon and Lant Pritchett. 2001. "Estimating Wealth Effects without Income or Expenditure Data - or Tears: Education Enrollment in India," Demography 38, 1: 115-132.

Fergany, Nader. (1998). "The Growth of Poverty in Egypt". Almishkat Center for Research. Working Paper No. 12. Egypt.

Fuchs, V.R., (1989). “Women's quest for economic equality". Journal of Economics Perspectives. No. 3, pp 25-41.

Gill, M.A. (1988). "Choice of employment status and the wages of employees and the self-employed: some further evidence", Journal of Applied Econometrics, 3 (3), pp 229-34.

Gollas, M. (1972). "Surplus labor and economic efficiency in the traditional sector of a dual economy: the Guatemalan case". Journal of Development Studies. Vol 8, No.4.

Gronau, R. (1974). "Wage comparisons - a selectivity bias", Journal of Political Economy, 82, pp 1119-44.

Ham, J.C. (1982). "Estimation of a labor supply model with censoring due to unemployment and underemployment", Review of Economic Studies, 49(3), pp 33554.

Hanoch, G. (1965). "The backward-bending supply of labor". Journal of Population and Economics. Vol (73). Dec., pp636-642.

Heckman, J.J. (1974). "Shadow prices, market wages, and labor supply", Econometrica, 42 (4), pp 679-94.

Heckman, J.J. (1979). "Sample selection bias as a specification error", Econometrica, 47(1), pp 153-61.

Killingsworth, M.R. (1983). Labor Supply, Cambridge: Cambridge University Press.

Killingsworth, M.R. and J.J. Heckman (1986). "Female labor supply: a survey." In Handbook of Labor Economics, Vol. I, O. Ashenfelter and R. Layard (eds.). Amsterdam: North-Holland, pp 102-204.

Lee, L., (1979). "Identification and estimation in binary choice models with limited (censored) dependent variables", Econometrica, 47(4), pp 977-96.

Lewis, H.G., (1974). "Comments on selectivity biases in wage comparisons", Journal of Political Economy, 82, pp 1145-57.

Lipton, M. (1983). "Labor and Poverty". World Bank Staff Working Paper. No. 616. World Bank, Washington, D. C.

Magnac, T. (1991). "Segmented or competitive labor markets", Econometrica, 59(1), pp165-87. 
Miracle, M.P., Fetter, B. (1970). "Backward-Sloping labor supply functions and African economic behavior. Economic Development and Cultural Change. Vol. (18), Jan. pp 240-251.

Moore, R. (1983a). "Employer discrimination: evidence from self-employed workers". Review of Economics and Statistics 65(3) pp 496-501.

Moore, R. (1983b). "Self-employment and the incidence of the payroll tax". National Tax Journal 36(4) pp 491-501.

Myrdal, G. (1971). Asian Drama: An Inquiry into the poverty of nations. Pantheon Books, New York.

Nakamura, M.; A. Nakamura, D. Cullen (1979). "Job opportunities, the offered wage, and the labor supply of married women", American Economic Review, 69(5), pp 787-805.

Poirier, D.J. (1980). "Partial observability in bivariate probit models", Journal of Econometrics, pp 209-17.

Psacharopoulos, G. and Z. Tzannatos (1989). "Female labor force participation: An international perspective," World Bank Research Observer, 4 (2), pp187-202.

Rees, H., and Shah, A. (1986). "An empirical analysis of self-employment in the U.K". Journal of Applied Econometrics 1(1) pp 95-108.

Robins, L. (1930). "On the Elasticity of Demand for Income in Terms of Effort. Economica (29), pp123-129.

Roy, A.D. (1951). "Some thoughts on the distribution of earnings". Oxford Economic Papers. No. 3, pp 135-46.

Sahn, David E., and Harold Alderman. (1988). "The effects of human capital on wages and the determinants of labor supply in a developing country". Journal of Development Economics, 29, pp 157-183.

Schultz, T.P. (ed.) (1995). Investment in Women's Human Capital. Chicago: The University of Chicago Press.

Schultz, T. W. (1964). Transforming Traditional Agriculture. Yale University Press, New Haven.

Shah, Nasra M., and Sulayman S. Al-Qudsi. (1990). "Female work roles in traditional, oil economy: Kuwait", in Research in Human Capital and Development, Ismail Serageldin, (ed.), Vol. 6, pp 213-246.

Sharif, M. (1991). "Poverty and the forward-falling labor supply function: a microeconomic analysis. World Development. Vol (19), No. 8, pp1075-1093.

Tansel, A. (1996). "Self-employment, wage-employment, and returns to education in Turkey." In Education and the Labor Market in Turkey. T. Bulutay (ed). Ankara: State Institute of Statistics Press, pp 175-208. 
Tansel, A. (1997). "Informal sector earnings determination in Turkey," Paper presented at the $4^{\text {th }}$ Annual Conference of ERF in Beirut.

Tiefenthaler, J. (1994). "A multisector model of female labor force participation: empirical evidence from Cebu Island, Philippines", Economic Development and Cultural Change, pp 719-42.

Tunal, İ. (1986). "A general structure for models of double-selection and an application to a joint migration/earnings process with re-migration." In Research in Labor Economics, Vol. 8, Part B. Greenwich: JAI Press, pp 235-82.

Tunal, İ. and C. Başlevent (2001). "Estimation of female labor supply parameters when self-employment is an option." Paper presented at the Annual ERF Conference held in Amman.

Tunal1, I. and H. Ercan (1998). "Labor market segmentation in Turkey", in Main Characteristics and Trends of the Turkish Labor Market, T. Bulutay (ed.). Ankara: State Institute of Statistics Printing Division.

Vella, F. (1998). "Estimating models with sample selection bias: a survey", Journal of Human Resources, 33 (1), pp127-69.

Yuengert, A. (1994). "Testing hypotheses of immigrant self-employment". Journal of Human Resources 30(1), pp 194-204.

Zabel, J.E. (1993). "The relationship between hours of work and labor force participation in four models of labor supply sehavior", Journal of Labor Economics, 11 (2), pp 387-416. 